\title{
INTERVENSI ULTRASOUND DAN PERTURBATION EXERCISE LEBIH EFEKTIF DARIPADA ULTRASOUND DAN MOBILIZATION WITH MOVEMENT UNTUK MENINGKATAN KEMAMPUAN FUNGSIONAL PADA PENDERITA OSTEOARTHRITIS GENU
}

\author{
I Putu Yudi Pramana Putra ${ }^{1}$, Dewa Putu Sutjana ${ }^{2}$, Wahyuddin ${ }^{3}$, Ketut \\ Tirtayasa $^{4}$, Luh Putu Ratna Sundari ${ }^{5}$, Muh. Irfan ${ }^{6}$ \\ ${ }^{1}$ Program Studi Magister Fisiologi Olahraga Universitas Udayana Denpasar Bali \\ ${ }^{2,4,5}$ Fakultas Kedokteran Universitas Udayana Denpasar Bali \\ ${ }^{3}$ Fakultas Fisioterapi Universitas Esa Unggul Jakarta \\ ${ }^{6}$ Program Studi Fisioterapi Stikes Aisyiyah Yogyakarta
}

\begin{abstract}
ABSTRAK
Pendahuluan: Osteoarthritis adalah salah satu keluhan pada sendi penumpu berat badan dengan sifat degeratif dan kronis sehingga mengakibatkan perubahan pada struktur kartilago sendi yang berdampak pada tulang, jaringan lunak dan cairan synovial seperti adanya nyeri, keterbatasan range of motion (ROM), deformitas dan adanya morning stiffness pada lutut. Tujuan: Mengetahui efektifitas antara intervensi ultrasound dan perturbation exercise dengan ultrasound dan mobilization with movement terhadap peningkatan kemampuan fungsional pada penderita osteoarthritis genu. Metode: Penelitian ini menggunakan metode eksperimental dengan rancangan pre dan post test control group design. Subjek pada penelitian ini berjumlah 22 orang yang dibagi menjadi 2 kelompok, dimana pada kelompok $1(\mathrm{n}=11)$ mendapatkan intervensi ultrasound dan perturbation exercise dan kelompok 2 diberikan intervensi ultrasound dan mobilization with movement dengan intensitas latihan 2 kali perminggu sebanyak 12 kali. Tehnik pengambilan sampel dengan consecutive sampling. Kemampuan fungsional diukur dengan menggunakan skala WOMAC. Hasil: Kelompok 1 didapatkan hasil $\mathrm{p}=0,001(\mathrm{p}<0,05)$ dan pada Kelompok 2 didapatkan hasil $\mathrm{p}=0,001(\mathrm{p}<0,05)$ untuk hasil Uji Paired Sample T-test. Uji beda nilai rerata dengan independent sample t-test setelah perlakuan ditemukan peningkatan kemampuan fungsional $21,45 \pm 4,132$ pada kelompok 1 dan 11,55 $\pm 1,368$ pada kelompok 2 dengan hasil $\mathrm{p}=0,036(\mathrm{p}<0,05)$. Simpulan: Intervensi ultrasound dan perturbation exercise lebih efektif dibandingkan dengan ultrasound dan mobilization with movement untuk meningkatkan kemampuan fungsional pada penderita osteoarthritis genu. Saran: Untuk peneliti selanjutnya dapat dilakukan follow up research untuk melihat hasil jangka panjang pemberian Intervensi ultrasound, perturbation exercise dan mobilization with movement untuk meningkatkan kemampuan fungsional pada penderita osteoarthritis genu.
\end{abstract}

Kata Kunci; Osteoarthritis genu, perturbation exercise, mobilization with movement, ultrasound, WOMAC. 


\title{
INTERVENTION OF ULTRASOUND AND PERTURBATION EXERCISE IS MORE EFFECTIVE COMPARED WITH ULTRASOUND AND MOBILIZATION WITH MOVEMENT FOR IMPROVING FUNCTIONAL ABILITY OF PEOPLE WITH OSTEOARTHRITIS GENU
}

\begin{abstract}
Background: Osteoarthritis is some of problem on joint which have a function for supporting body and have chronic and degenerative characteristic so it can affects the cartilaginous structure of joint it can cause some of abnormality of bones, soft tissues, and synovial fluid like pain, decrease on range of motion (ROM), deformity and morning stiffness which is most often felt especially in knee joint. Purpose: This study was to determine affectivity combination intervention of ultrasound and perturbation exercise with ultrasound and mobilization with movement to improve functional ability for people with osteoarthritis genu. Methods: This research used experimental method with pre and post test control group design. Subject of this research are 22 people and divided into two groups where on the group 1 was given intervention of ultrasound and perturbation exercise and group 2 was given intervention of ultrasound and mobilization with movement with intensity 2 times per week for 12 times total intervention. Measurement functional score ability improvement was measured using a WOMAC index. Result: Group 1 result obtained $\mathrm{p}$ value $=0.001(\mathrm{p}<0.05)$ and in Group 2 got result obtained $\mathrm{p}$ value $=0.001(\mathrm{p}<0.05)$ for Paired Sample T-test. Different test of mean value with independent sample t-test after treatment found that the increase of improve functional $21.45 \pm 4.132$ in group 1 and $11.55 \pm 1.368$ in group 2 with $\mathrm{p}$ value $=0.036$ ( $p$ <0.05). Conclusion: Intervention of ultrasound and perturbation exercise is significantly more effective compared with ultrasound and mobilization with movement for improve functional ability for people with osteoarthritis genu. Suggestion: For the next researcher can do follow up research to see long-term result intervention of ultrasound, perturbation and mobilization with movement for improve functional ability for people with osteoarthritis genu.
\end{abstract}

Key Word; Osteoarthritis genu, perturbation exercise, mobilization with movement, ultrasound, WOMAC

\section{PENDAHULUAN}

Bergerak memiliki peranan penting dalam proses kehidupan manusia. Gerak menjadi komponen dasar yang essensial untuk terpenuhi dalam proses beraktivitas. Kegiatan sehari-hari seperti memasak, mencuci, berlari dan yang lainnya memerlukan suatu proses bergerak dengan pola yang kompleks. Kemunduran dari sistem gerak tubuh manusia akan mempengaruhi kualitas dari gerakan yang dihasilkan seperti penuaan yang terjadi pada kelompok usia lanjut (lansia).

Manusia pada hakekatnya akan menjalani proses penuaan yang akan berpengaruh pada sistem penggerak utama tubuh yaitu tulang dan otot sebagai eksekutor gerakan. Penuaan merupakan suatu keadaan dimana tubuh tidak dapat memenuhi kebutuhan fisiologis yang ditandai dengan penurunan fungsi yang terjadi secara perlahan. Pada usia lanjut sistem eksekutor gerakan akan 
mengalami degenerasi dan masalah penurunan fungsi yang terjadi secara perlahan.

Osteoarthirtis (OA) merupakan salah satu dari jenis penyakit degeneratif kronik dan progresif terhadap perubahan fisiologis penuaan dan pada sendi-sendi besar yang menumpu berat badan. Angka kejadian $O A$ akan semakin meningkat seiring dengan pertambahan usia dimana kelompok usia lanjut dengan jumlah kasus 60\%-70\% terjadi pada usia 5069 tahun $^{1}$. Jenis kelamin juga berpengaruh terhadap prevalensi penderita $O A$ dimana sekitar 9,6\% pada laki-laki dan $18 \%$ terjadi pada perempuan ${ }^{8}$.

Osteoarthritis merupakan jenis arthritis yang menyerang sendi-sendi besar penopang berat badan seperti tulang belakang, panggul, lutut (genu) dan pergelangan $\mathrm{kaki}^{10}$. Prevalensi $O A$ genu sendiri yang cukup tinggi, $14 \%$ terjadi pada laki-laki dan 22,8\% terjadi pada perempuan di Amerika dan Eropa yang berumur 45 tahun keatas ${ }^{2}$. Pada $O A$ genu terjadi destruksi dan pengikisan kartilago di permukaan tulang femur dan tibia yang menimbulkan gesekan pada kedua permukaan tulang tersebut sehingga mengakibatkan terjadinya keluhankeluhan pada sendi.

Adanya patologi yang terjadi pada sendi lutut dalam kejadian $O A$ genu akan menghambat seseorang untuk melakukan tugas fungsionalnya dengan baik. Nyeri yang dirasakan pada penderita OA genu akan membuat penurunan dari kontraksi fungsional dari otot-otot stabilisator lutut menjadi kontraksi tidak sinergis (non-fisiologis) ${ }^{4}$.

Pengobatan yang diberikan pada osteoarthritis secara nonfarmakologis dapat berupa mobilisasi sendi lutut, program latihan berupa quadriceps strengthening dan pengaplikasian modalitas ultrasound ${ }^{5}$.
Pemberian modalitas ultrasound therapeutic (US) dapat digunakan untuk mempercepat proses pertumbuhan jaringan baru dan menurunkan nyeri yang dirasakan ${ }^{7}$. Penelitian terbaru juga menemukan adanya peningkatan yang signifikan dari kemampuan fungsional seseorang setelah diberikan teknik mobilisasi.

Perturbation exercise merupakan suatu bentuk latihan modifikasi, dalam aplikasinya melibatkan gaya eksternal (external force) dalam mengacaukan kestabilan sendi lutut agar mengalami gangguan dengan tujuan meningkatkan neuromuscular awareness, neuromuscular response dan stabilitas dinamis pada lutut dalam stabilisasti sendi. Perturbation exercise dapat diberikan pada kasus $O A$ genu dengan mengedepankan konsep kneeprotective neuromuscular response, hal ini akan meningkatkan respon pasien terhadap gaya eksternal yang mengganggu saat aktivitas fungsional seperti berjalan, naik-turun tangga duduk ke berdiri dan lain-lain. Tujuannya adalah pasien $O A$ genu mampu memberikan respon yang cepat, spesifik dan efisien ketika adanya perpindahan dan percepatan gaya yang sangat esensial terjadi selama melakukan aktifitas fungsional. Respon ini akan menghasilkan gerakan yang sinergis sehingga dapat mengurangi abnormalitas pembebanan pada kartilago sendi ${ }^{3}$.

Penurunan dari kemampuan aktivitas fungsional pada pasien $O A$ genu juga dapat ditingkatkan dengan teknik mobilisasi sendi. Terdapat jenis latihan dan teknik mobilisasi sendi yang dapat diaplikasikan pada pasien. Teknik mobilization with movement $(M W M)$ yang ditemukan oleh Brian Mulligan merupakan salah satu teknik mobilisasi yang sedang berkembang di dunia saat ini dimana accessory mobilization diberikan oleh terapis dan 
active physiological movement hingga akhir lingkup gerak sendi yang dilakukan secara aktif oleh pasien. Mulligan berpendapat bahwa cidera/ nyeri akibat kesalahan posisi (positional fault) dapat menyebabkan gerakan sendi yang terbatas dan pembebanan yang berlebihan pada permukaan sendi sehingga memprovokasi nyeri gerak yang timbul. Aplikasi dari Mulligan's mobilization with movement mengembalikan kesalahan posisi (positional fault) yang terjadi sesuai dengan osteokinematika dan arthrokinematika ketika pasien melakukan gerak fisiologis dengan syarat gerakan yang dilakukan harus pain-free atau tidak memprovokasi nyeri. Sedangkan gerakan fisiologis secara aktif yang dilakukan pada aplikasinya dapat membantu menjaga dan meningkatkan kekuatan otot yang berfungsi sebagai stabilisator sendi. Selain itu teknik $M W M$ juga dapat merangsang saraf proprioceptik sendi sebagai reseptor gerakan pada sendi untuk dapat mengembalikan pembebanan sendi yang fisiologis sehingga memberikan peningkatan lingkup gerak sendi dan menurunkan nyeri yang biasanya menjadi penghalang dalam melakukan aktivitas fungsional pasien $O A$ genu $^{10}$.

\section{METODE PENELITIAN}

\section{A. Rancangan Penelitian}

Desain pada penelitian yang telah dilakukan disini adalah pre dan post-test control group design dengan menggunakan

rancangan eksperimental. Desain penelitian ini membandingkan perlakuan antara dua kelompok kombinasi. Kelompok 1 yaitu intervensi ultrasound dan perturbation exercise dan Kelompok 2 yang diberikan kombinasi intervensi ultrasound dan mobilization with movement. Masing masing kelompok terdiri dari 11 orang penderita $O A$ genu.

\section{B. Tempat dan Waktu Penelitian}

Penelitian dilakukan pada penderita osteoarthritis genu dari bulan Januari sampai Maret 2018 di Klinik Fisioterapi Merdeka Medical Centre $(M M C)$ di daerah Denpasar. Total intervensi diberikan sebanyak 12 kali intervensi, dengan frekuensi 2 kali dalam seminggu.

\section{Populasi dan Sampel}

Seluruh pasien yang terindikasi $O A$ genu dari asesmen yang dilakukan adalah populasi target pada penelitian ini. Sedangkan pada populasi terjangkau dalam penelitian ini adalah seluruh pasien yang terindikasi $O A$ genu dan telah memenuhi kriteria inklusi serta eksklusi masuk sebagai sampel di penelitian ini.

\section{Teknik Pengambilan Sampel}

Teknik pengambilan sampel accidental dan consecutive sampling merupakan teknik pengambilan sampel dalam penelitian ini. Sampel yang terpilih dirandomisasi dengan cara undian untuk mendapatkan 22 sampel sesuai dengan jumlah sampel yang dibutuhkan sesuaidengan inklusi, ekslusi dan asesmen fisioterapi yang telah dilakukan.

\section{E. Prosedur Penelitian}

Prosedur penelitian ini adalah: Tahap persiapan dan Tahap Pelaksanaan.

Tahap Persiapan : (a) Meminta ijin kepada Merdeka Medical Center (MMC) sebagai tempat melakukan penelitian; (b) Peneliti membuat surat ijin penelitian dan ditandatangani Ketua Prodi Fisiologi Olahraga; (c) Peneliti memberikan penjelasan kepada sampel; (d) Populasi mengisi blangko inform consent. 
Tahap pelaksanaan: (a) Melakukan anamnesis dan pemeriksaan fisik sampel; (b) Menetapkan sampel kelompok 1 dan 2 secara acak yang memenuhi kriteria inklusi dan asesmen fisioterapi; (c) Melakukan pengukuran fungsional awal dengan WOMAC index; (d) Pemberian intervensi ultrasound dan perturbation exercise pada Kelompok 1 dan pemberian intervensi ultrasound dan mobilization with movement pada Kelompok 2 selama 2 kali seminggu selama 12 kali perlakuan; (e) Melakukan pengukuran peningkatan fungsional akhir dengan WOMAC index.

\section{F. Analisis Data}

1.Statistik deskriptif untuk menggambarkan karakteristik fisik yang meliputi umur,berat badan dan MMT.

2.Uji normalitas data menggunakan Saphiro Wilk Test untuk mengetahui distribusi data.

3. Uji homogenitas untuk mengetahui variasi data dengan menggunakan Levene Test

4. Uji hipotesis I dan II menggunakan Paired Sample t-test yang bertujuan menguji adanya perbedaan hasil pre dan post intervensi.

5.Uji hipotesis III menggunakan Independent Samples t-test untuk menguji signifikansi antara kelompok 1 dan kelompok 2.

\section{HASIL PENELITIAN}

\section{Deskripsi Karakteristik Subjek} Penelitian

Tabel 5.1

Distribusi Data Sampel

\begin{tabular}{llll}
\hline Karakteristik & $\begin{array}{l}\text { Klp 1 } \\
\mathrm{n}=11\end{array}$ & $\begin{array}{l}\text { Klp 2 } \\
\mathrm{n}=11\end{array}$ & Nilai p \\
\hline Jenis & & & \\
Kelamin (\%) & & & \\
Laki-Laki & 27,3 & 27,3 & 1,00 \\
$\begin{array}{l}\text { Perempuan } \\
\text { Umur }\end{array}$ & 72,7 & 72,7 & \\
(tahun) & & & \\
Mean \pm SD & $58,36 \pm 5,33$ & $56,73 \pm 4,61$ & 0,450 \\
\hline
\end{tabular}

\section{Uji Normalitas dan Homogenitas}

Uji normalitas dengan Saphiro Wilk test dan homogenitas memakai Levene's test, hasilnya ada pada Tabel 5.2

Tabel 5.2

Hasil Uji Normalitas dan Homogenitas

\begin{tabular}{cccccc}
\hline & \multicolumn{4}{c}{ Uji Normalitas dengan Shapiro Wilk } & $\begin{array}{l}\text { Uji } \\
\text { Kest }\end{array}$ \\
\cline { 2 - 5 } $\begin{array}{l}\text { Komog } \\
\text { Data }\end{array}$ & Klp 1 & P & Klp 2 & P & enitas \\
\hline $\begin{array}{c}\text { Nilai } \\
\text { Pre }\end{array}$ & 0,890 & 0,138 & 0,890 & 0,138 & 1,000 \\
$\begin{array}{c}\text { Nilai } \\
\text { Post }\end{array}$ & 0,893 & 0,152 & 0,819 & 0,117 & 0,825 \\
\hline
\end{tabular}

Berdasarkan tabel diatas hasil uji normalitas menunjukkan nilai $\mathrm{p}>0,05$ yang menyatakan data berdistribusi normal. Hasil dari uji homogenitas menggunakan Levene's test menunjukkan $\mathrm{p}>0,05$ menyatakan bahwa kedua kelompok bersifat homogen.

\section{Uji Beda Penurunan Nyeri Otot Betis Sebelum dan Sesudah Perlakuan}

Tabel berikut ini merupakan hasil paired sample t-test sebelum dan setelah perlakuan di Kelompok 1 dan Kelompok 2 bernilai $\mathrm{p}=0,001$ $(\mathrm{p}<0,05)$ berarti terdapat perbedaan yang bermakna pada adanya peningkatan kemampuan fungsional sebelum dan setelah diberikan Kombinasi intervensi.

Tabel 5.3.

Uji Paired Sample t-test dan Independent Sample t-test

\begin{tabular}{lllll}
\hline & $\begin{array}{l}\text { Sebelum } \\
\text { Intervensi }\end{array}$ & $\begin{array}{l}\text { Setelah } \\
\text { Intervensi }\end{array}$ & Beda Rerata & P* \\
\hline Klp 1 & 49,82 & 26,73 & $23,09 \pm 1,480$ & 0,001 \\
Klp 2 & 48,82 & 30,36 & $18,45 \pm 4,741$ & 0,001 \\
\hline $\mathrm{P}^{* *}$ & 0,717 & 0,003 & & \\
\hline
\end{tabular}

Keterangan :

$\mathrm{p}^{*}$ : Hasil Uji Beda Menggunakan Paired Sample t-test $\mathrm{p}^{* *}$ : Hasil Uji Beda Menggunakan Independent Sample t-test

Hasil dari analisis independent sample t-test terjadi peningkatan kemampuan fungsional sebelum 
maupun sesudah perlakuan di Kelompok 1 dan Kelompok 2 yang ditunjukkan dengan nilai $\mathrm{p}=0,036(\mathrm{p}$ $<0,05)$ setelah latihan, yang artinya intervensi kelompok 1 lebih baik daripada kelompok 2.

\section{PEMBAHASAN}

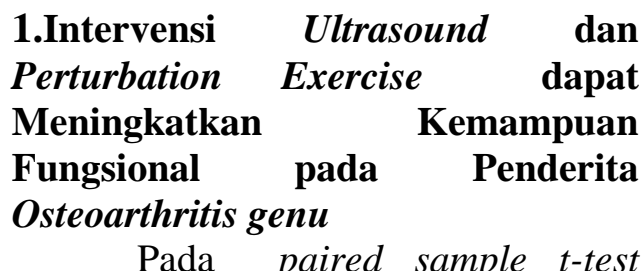
kelompok perlakuan 1, didapatkan skor WOMAC sebesar 49,82 $\pm 6,36$ sebelum intervensi dan setelah intervensi sebesar $26,73 \pm 2,32$. Selain itu, diperoleh nilai $\mathrm{p}=0,001(\mathrm{p}<0,05)$.

Hasil yang diperoleh dalam penelitian ini sesuai dengan teori yang dipaparkan oleh Brotzman dan Manske $^{4}$ dimana perturbation exercise dapat menurunkan keluhan yang ditimbulkan $O A$ dan meningkatkan fungsional pada lutut dengan mekanisme knee-protective neuromuscular response. Peran dari mekanisme tersebut sangat penting dalam memberikan edukasi kepada pasien untuk dapat menghasilkan kontraksi otot yang bersifat selektif dan adaptif untuk dapat merespon dari gaya eksternal dengan memberikan pelatihan untuk meningkatkan neuromuscular response dan neuromuscular awarness.

Menurut Mansfield, et al., ${ }^{12}$ adanya peningkatan sudut valgus dan varus sebagai akibat hilangnya mekanika sendi yang normal, penurunan fungsi serta ketidakseimbangan kontraksi dari otototot stabilitator sendi lutut dapat dilatih dengan menfasilitasi balance recovery reaction. Mekanisme tersebut dapat perbaiki abnormalitas pembebanan yang berlebih pada permukaan sendi dan memberikan pembelajaran pada otot-otot stabilitator dan mobilitator pada sendi lutut untuk dapat bekerja secara sinergis.

Selain itu Fitzgerald, et al., ${ }^{9}$ dalam penelitiannya memaparkan dalam perturbation exercixe pasien akan diberikan gangguan berupa perubahan gaya yang cepat dan random dengan tujuan untuk meningkatkan input proprioseptive pada kapsul sendi dan otot tungkai sehingga akan memberikan stimulus kontraksi pada otot-otot stabilitator lutut yang cepat dan efisien. Efisien yang dimaksud adalah kontraksi yang dihasilkan hampir sama ataupun sama dengan gaya eksternal yang terjadi, hal tersebut akan menghasilkan gerakan halus dan terkendali sehingga pasien dapat dengan mudah untuk mengontrol dan mengantisipasi dari perubahan gaya yang terjadi selama melakukan aktivitas fungsionalnya sehari-hari.

Modalitas fisioterapi US therapeutic diaplikasikan pada lutut pasien sebelum melakukan perturbation. Menurut teori yang disampaikan oleh Draper \& Prentice ${ }^{6}$, US therapeutic sangat efektif dalam menghilangkan sel-sel yang bertanggung jawab terhadap nyeri dan memfasilitasi pertumbuhan jaringan ikat baru dengan memodifikasi simtoms nyeri pada lutut. Pemberian US therapeutic pada OA genu dapat memperbaiki kerusakan pada kartilago sendi dengan menstimulasi poliferasi kondrosit dan produksi matriks tulang yang membantu memberikan penurunan dari nyeri yang dirasakan pasien. Teori tersebut didukung oleh Leong et al., ${ }^{11}$ dimana pemberian low intensity pulsed ultrasound terbukti dapat menfasilitasi menurunkan keluhan yang dirasakan pada pasien оА gепи. 
2.Intervensi Ultrasound dan Mobilization With Movement dapat Meningkatkan Kemampuan Fungsional pada Penderita Osteoarthritis genu

Hasil paired sample t-test pada kelompok didapatkan skor WOMAC 48,82 $\pm 6,36$ sebelum intervensi sebesar dan setelah intervensi sebesar $30,36 \pm 2,73$. Selain itu, diperoleh nilai $\mathrm{p}=0,001(\mathrm{p}<$ $0,05)$

Hasil penelitian ini sesuai dengan penelitian yang dilakukan oleh Alagesan $^{2}$ mengenai efek dari Mulligan's $M W M$ pada pasien dengan keluhan $O A$ genu dimana terjadi peningkatan lingkup gerak sendi terhadap penderita $O A$ genu. Menurut Mulligan ${ }^{13} M W M$ dapat memperbaiki malalignment sendi dan mengurangi nyeri secara drastis.

Selain itu Eugeniya $^{8}$ memaparkan $M W M$ memberikan perubahan yang signifikan terhadap penurunan nyeri dan keterbatasan gerak terutama yang disebabkan oleh adanya kesalahan posisi (positional foult) dengan mengaplikasikan pasif accessory mobilization dan active physiological movement. Pemberian roll dan glide sebagai accessory mobilization yang diberikan secara pasif pada aplikasi $M W M$ bertujuan untuk memperbaiki posisi dan mengembalikan pembebanan sendi secara merata sedangkan gerakan fleksi dan ekstensi sebagai gerak active physiological akan merangsang proprioseptik sendi untuk mengetahui posisi yang sesuai dengan osteokinematika dan arthrokinematika sendi sehingga hal tersebut akan dapat menurunkan nyeri gerak yang dapat mengurangi kualitas dari aktivitas fungsional sehari-hari ${ }^{5}$.

Sebelum dilakukan intervensi didahului dengan pemberian $U S$ therapeutic sehingga dapat membantu memfasilitasi pelepasan histamin dari mast cells yang akan melepaskan agen perbaikan jaringan ikat baru, hal tersebut akan membuat percepatan dari penurunan inflamasi jaringan pada lutut yang berhubungan dengan nyeri dan kekakuan gerak. Berkurangnya nyeri gerak dan nyeri tekan pada lutut akan berdampak besar dalam mempermudah proses latihan dan aktivitas fungsional pada pasien $O A$ genu ${ }^{6}$.

\section{Intervensi Ultrasound dan} Perturbation Exercise Lebih Efektif daripada Ultrasound dan Mobilization With Movement untuk Meningkatkan Kemampuan Fungsional pada Osteoarthritis genu

Dari independent t-test, dapat ditemukan nilai selisih penurunan skor WOMAC pada kelompok perlakuan 1 sebesar $(23,09 \pm 4.908)$ dan kelompok perlakuan 2 sebesar $(18,45 \pm 4,740)$. Selain itu, diperoleh nilai $\mathrm{p}=0,036$ $(p<0,05)$. Dimana hal tersebut dapat menjadi indikasi kombinasi intervensi kelompok 1 lebih baik daripada kelompok 2.

OA gепи merupakan suatu keadaan dimana lutut sebagai sendi yang menopang masa tubuh yang dominan terjadi degenerasi jaringan. Nyeri dan keterbatasan gerak pada lutut menjadi hambatan pasien untuk dapat melakukan aktivitas fungsionalnya sehari-hari. Oleh karena itu disimpulkan bahwa kombinasi dari intervensi perturbation exercise dan mobilization with movement dengan US therapeutic memiliki efek, mekanisme dan nilai yang berbeda dalam meningkatkan kemampuan fungsional pada penderita $O A$ genu.

$$
\text { Perturbation exercise }
$$

tergolong baru dan jarang digunakan pada pasien $O A$ genu dimana terjadi instabilitas sendi lutut. Menurut teori yang disampaikan oleh Brotzman dan Manske $^{4}$, prinsip dari perturbation exercise yaitu mengaktifkan 
neuromuscular awareness, neuromuscular response pada lutut untuk menstabilisasi sendi tersebut sehingga memperoleh knee-protective neuromuscular response yang berperan selama proses gerak. Hal tersebut didukung oleh Fitzgerald, et al. ${ }^{9}$ yang dalam penelitiannya mengatakan bahwa knee protective neuromuscular response merupakan suatu mekanisme dimana reseptor pada sendi teraktivasi sehingga dapat mengedukasi dan memfasilitasi proprioceptif sendi agar dapat menghasilkan reaksi otot yang selektif, sinergis dan adaptif dalam merespon gaya yang diadministrasikan pada bidang permukaan tumpuan yang berubah ubah dalam tujuan melindungi sendi dari gaya eksternal pada lutut selama bergerak.

$M W M$ dapat meningkatkan fungsional sendi lutut dikarenakan adanya perbaikan dari positional foult pada lutut yang menghasilkan nyeri dan kekakuan gerak yang akan menurunkan lingkup gerak sendi dengan aplikasi pasif accessory mobilization yang diberikan oleh terapis dan active physiological movement yang dilakukan oleh pasien $^{10}$. Selain itu Kisner dan Colby menerangkan bahwa $M W M$ dapat menghasilkan beberapa mekanisme yang terkait dengan peningkatan kemampuan fungsional seperti mengaktifkan proprioseptor melalui aproksimasi sendi serita kontraksi multiple pada otot-otot agonis dan antagonis.

Hasil dari penelitin ini menunjukan terdapat perbedaan yang signifikan antara kombinasi US therapeutic dengan intervensi perturbation yang lebih baik daripada $M W M^{4}$. Pada $M W M$, dalam latihannya hanya terjadi gerakan fleksi-ekstensi lutut sebagai gerakan aktif dan dikombinasikan dengan gerak asesori. Hal yang berbeda terjadi pada proses perturbation exercise, dimana dalam aplikasinya latihan ini melibatkan gaya dari berbagai arah secara random. Hal tersebut merupakan suatu gambaran mengenai respon lutut dari hambatan ataupun kondisi permukaan dari bidang tumpu yang tidak selalu datar dan antisipasi dari gaya ekternal yang kemungkinan besar dapat terjadi pada proses aktivitas ${ }^{15}$.

Berdasarkan kajian yang telah dibahas sebelumnya penurunan stabilisasi pada pasien $O A$ genu baik perturbation exercise ${ }^{9}$ maupun $M W M^{17}$ dapat menghasilkan efek yang baik dengan menfasilitasi kontraksi otot agonis dan antagonis. Dalam perturbation exercise respon kokontraksi secara spesifik sesuai dengan gaya yang teraplikasi, cepat berkaitan dengan lamanya respon yang dihasilkan setelah gaya teraplikasi dan efisien berkaitan dengan kesesuaian besar gaya yang kita hasilkan terhadap gaya eksternal yang terjadi, menjadikan latihan ini lebih sesuai dilakukan pada pasien $O A$ genu daripada $M W M^{12}$.

Menurut Dziedzic dan Hammond ${ }^{10}$ lutut sebagai akibat dari OA genu akan memperbesar kemungkinan pasien untuk hilang keseimbangan bahkan resiko jatuh. Perturbation exercise mampu secara signifikan mengatasi perihal hilanganya keseimbangan yang dialami pada pasien dengan menghasilkan balance recovery reaction. Mekanisme ini akan melatih kecepatan reaksi untuk memperoleh keseimbangan yang baru dalam merespon perubahan gaya yang terjadi $^{12}$. Permasalahan mengenai respon pasien untuk mengatasi dan mencegah jatuh tersebut tidak ditemukan pada latihan $M W M$ yang menjadikan salah satu perbedaan dari efektifitas kedua latihan ini dalam menangani masalah OA genu.

Berdasarkan hasil kajian teori, baik perturbation exercise maupun 
mobilization with movement telah berhasil mencakup komponenkomponen penting pada lutut seperti aproksimasi lutut untuk dapat memberikan stimulasi pada reseptor yang membantu kongruenitas sendi dimana hal tersebut akan berperan dalam stabilitas sendi dan aktivasi otot yang multiple yang berpengaruh dalam menghasilkan gerakan yang halus dan sinergis ${ }^{14}$.

Perbedaan yang terpenting dari perturbation exercise dengan mobilization with movement adalah adanya peran dari awarness, balance recovery reaction dan adanya perpindahan gaya yang difasilitasi dari perturbation exercise $e^{12}$.

Berdasarkan beberapa kajian teori dan hasil penelitian dapat disimpulkan bahwa peningkatan kemampuan fungsional dapat dicapai secara signifikan oleh perturbation exercise dan $M W M$ dengan aplikasi $U S$ therapeutic terlebih dahulu melalui komponen-komponen yang telah dijabarkan. Namun perturbation exercise lebih efektif jika dibandingkan dengan $M W M$ karena adanya kelebihan dari komponen penting yang diperoleh untuk meningkatkan kemampuan fungsional pasien $O A$ genu melaksanakan gerakan fungsional sehari-hari.

\section{SIMPULAN}

1.Intervensi

ultrasound dan perturbation exercise dapat meningkatkan kemampuan fungsional pada penderita OA genu.

2.Intervensi ultrasound dan mobilization with movement dapat meningkatkan kemampuan fungsional pada penderita $O A$ genu.

3.Intervensi ultrasound dan perturbation exercise lebih efektif daripada ultrasound dan mobilization with movement untuk meningkatkan kemampuan fungsional pada penderita OA gепи.

\section{DAFTAR PUSTAKA}

1. Akinpellu AO, Alonge TO, Adekanla BA, Odole AC. 2009. Prevalence and Pattern of Symptomatic Knee Osteoarthritis in Nigeria: Community-Based Study. The Internet Journal of Allied Health Science and Practice Vol 7 (3): 1-7

2. Alagesan J. Sailor S, Sambandam C. (2011). Effect of Mulligan Mobilization and Maitland Mobilization in Subjects with Unilateral Tibiofemoral Osteoarthritis - Randomized Controlled Trial. Journal of Pharmaceutical And Biomedical Sciences. Vol 11(17) :1-4

3. Arnold CM, Gyurcsik NC. 2012. Risk Factors for Falls in Older Adults with Lower Extremity Arthritis: A Conceptual Framework of Current Knowledge and Future Directions. Physiother Can 64(3): 302-314

4. Brotzman SR and Manske RC. 2011. Clinical Orthopaedic Rehabilitation. An Evidence Based Approach. Third Edition. Philadelphia. Elsevier: 219-222

5. Cheraladhan E, Sanbandam C, Sailor S .2011. Effect of Mulligan Mobilization and Maitland Mobilization in Subjects with Unilateral Tibiofemoral Osteoarthritis -Randomized ControlledTrial.;11:17.

6. Draper DO and Pretince WE. 2005. Therapeutic Modalities in Rehabilitation. third edition. United States of America: The McGraw-Hill Companies.

7. Ebrahim AHM. 2011. Myofascial Pain Syndrome Associated With Trigger Points: A Literature Review.(I) Epidemiology, Clinical Treatment and Etiopathogeny. Journal Section : Oral Medicine and Pathology Vol. 1, No. 14, 494-498 
8. Evgeniya D. 2008. Efficacy mobilization with of movement in patient with knee osteoarthritis. Sports Medicine Journal. 2008; 16

9. Goodman CC and Fuller KS. 2009. Pathology: Implications for Physical Therapist. Third Edition. Missouri. Elsevier: 1250 - 1258

10. Horak FB, Henry SM, Cook AS. 1997. Postural Perturbations : New Insight for Treatment of Balance Disorders. Phys Ther 77 : 517-533

11. Levangie PK and Norkin CC. 2007. Joint Structure and Function : A Comprehensive Analysis. Fourth edition. Philadelphia. F.A Davies Company : 393-491

12. Mody G dan Wolf A. 2003. A Report on the Global Burden Musculoskeletal Disorders. Business Briefing of European Pharmacotherapy Association. Available at: http://www.touchbriefings.com/pd f/26/ ept031_p_moody\& wolf_ir.pdf diakses tanggal 16 Januari 2015

13. Mulligan BR. 2004. Manual Therapy: "NAGS," SNAGS," $M W M S$," etc. 6th ed. Wellington,
New Zealand: Plane View Services LTD

14. Nursyarifah, R.S. 2012. Hubungan antara obesitas dengan kejadian osteoartritis lutut di RSUP dr. Kariadi Semarang. Semarang: Universitas Muhammadiyah Semarang.

15. Vicenzino B, Hall T, HingW, Rivett D 2011. A new proposed model of the mechanisms of action of mobilisation with movement. In: Vicenzino B, Hall T, Hing W, and Rivett D (eds) Mobilisation with Movement: The Art and the Science, pp 75-85. London, Churchill Livingstone 